\title{
Determination of Recurrent/Residual CIN-II and CIN-III After Leep, Cytology or HPV-DNA?
}

Leep Sonrası Rekürren/Rezidüel CIN 2-3 Belirlenmesi, Sitoloji mi, Hpv-Dna mı? Özgür ÇOBAN ${ }^{1}$, Hüseyin DURUKAN ${ }^{1}$, Talat Umut Kutlu DÍLEK ${ }^{1}$ Arzu DORUK ${ }^{1}$, Saffet DILEK ${ }^{1}$

\author{
1. Department of Obstetrics and Gynecology, Mersin University Faculty of Medicine, Mersin, Turkiye
}

\section{ABSTRACT}

Objective: Having some advantages, LEEP becomes the standard treatment of CIN-II and III lesions. However, failure to treatment after LEEP is also seen as in other treatment methods. This study aims to determine the value of cervical cytology, surgical margin positivity and $H P V-D N A$ testing for determination of residual or recurrent disease in patients undergone LEEP with the diagnosis of CIN II or III.

Material and Method: Colposcopy directed biopsy and endocervical curettage applied 77 cases six months after initial LEEP treatments were retrospectively analyzed. Histological examination is used in order to determine residual/recurrent disease. Cytology and HPV-DNA PCR tests after six months and initial surgical margin positivity at the time of LEEP were all compared.

Results: In 14 (18.1\%) of the 77 cases, residual/recurrent disease was determined. HR-HPV was positive in $13(17 \%)$ and negative in 64 (83\%). Recurrent/residual disease rate was found to be 12/13 (92\%) in HR-HPV positive cases and 2/64 (3\%) in HR-HPV negative cases. Out of 25 patients who were surgical margin positive, recurrent/residual disease was determined in 7 (28\%). Cytology was positive in 26 (33.8\%) cases. Recurrent/ residual disease was determined in 2 of the cytology negative and in 12 of the cytology positive cases.

In prediction of residual/recurrent disease, HPV testing was found to be superior to surgical margin positivity or conventional cytology.

Conclusion: HPV test may be considered primarily for determination of treatment failures after LEEP.

Keywords: HPV; Recurrent residual disease; CIN2; CIN3; LEEP

\section{Contact:}

Corresponding Author: Hüseyin DURUKAN

Address: Department of Obstetrics and Gynecology, Mersin University Faculty of Medicine, Mersin, Turkiye

Tel: +90 (324) 3374300

E-mail: huseyindurukan@gmail.com

Submitted: 12.06 .2016

Accepted: 10.10.2016

DOI: http://dx.doi.org/10.16948/zktb.09286

\section{ÖZET}

Amaç: Bazl avantajlara sahip olan LEEP uygulaması CIN-II ve III lezyonlarinin standart tedavisi haline gelmiştir. Ne yazık ki,diğer tedavi yöntemlerinde olduğu gibi tedavi başarısızlıkları LEEP uygulaması sonrasında da görülebilmektedir. Bu çalışma CIN II veya III nedeniyle LEEP yapılan olgularda rekürren/ rezidüel hastalık belirlenmesinde servikal sitoloji, cerrahi sınır pozitifliği ve HPV DNA testinin değerini ortaya koymayı amaçlamaktadir.

Gereç ve Yöntem: LEEP tedavisi uygulanmış ve altı ay sonrasında kolposkopi yönlendirilmiş biyopsi ve endoservikal küretaj yapılmış 77 olgu retrospektif olarak incelendi. Rekürren / rezidüel hastalık tespiti için histolojik inceleme uygulanmıştı. LEEP esnasındaki cerrahi sinır pozitiflig $i$, altı ay sonrasında alınan sitoloji ve HPV DNA PCR test sonuçları karşılaştırmaya dahil edildi.

Bulgular: Rekürren / rezidüel hastalık 77 olgunun 14'ünde $(\% 18,1)$ belirlenmiştir. HR-HPV 13 (\%17) olguda pozitif ve 64 (\%83) olguda negatifti. Rekürren / rezidüel hastalık oranı HR-HPV pozitif olgularda 12/13 (\%92), ve HR-HPV negatif olgularda 2/64 (\%3) olarak saptandi. Cerrahi sınır pozitifliği olan 25 olgunun ise 7 'sinde (\%28) rekürren / rezidüel hastalık saptandl. Sitoloji $26(\% 33,8)$ olguda pozitifti. . Rekürren / rezidüel hastalı sitolojis negatif olan 2 olguda ve sitolojisi pozitif olan 12 olguda saptand.

Rekürren / rezidüel hastalı öngörmede HPV testinin cerrahi marjin pozitifliğinden veya konvansiyonel sitolojiden daha üstün olduğu görüldü.

Sonuç: HPV testi LEEP sonrası tedavi başarısızlığını belirlemede ilk planda kullanilabilir.

Anahtar Kelimeler: HPV; Rekürren rezidüel hastallk; CIN 2; CIN 3; LEEP 


\section{INTRODUCTION}

Cervical cancer is a worldwide health problem. Every year over 470,000 new cases were diagnosed and over 230,000 women were thought to die because of this cancer (1). After early recognition and treatment of precursor lesions, quite satisfactory declines were achieved in incidence and mortality of cervix cancer in countries implementing national screening programs (2).

Precursor lesions of cervix cancer were called cervical intraepithelial neoplasia (CIN 1, 2, and 3). Untreated high grade (CIN 2 and 3) lesions may progress $(5-12 \%)$ to invasive cervical cancer in time. Thus, CIN 2 or 3 lesions should be treated when diagnosed. Emerging standard treatment model for these lesions is loop electrosurgical excision procedure (LEEP). This method provides the advantage of both histopathologic diagnosis and extraction of the lesion without extensive adjacent tissue destruction. As seen in other therapeutic approaches, treatment failures with LEEP method may also be encountered. Treatment failure called as recurrent or residual disease should also be urgently treated in no time. Follow-up is a necessary practice, in order to early detect recurrent/residual disease cases (5-30\%) after CIN 2/3 treatment (3).

Low sensitivity and high false negative rates of traditional cervical cytological screening test in detection of these cases following LEEP necessitates the research for development of new diagnostic methods. Recently revealed strong causal relationship between CIN and high risk human papillomavirus (HR-HPV) types directed us to search for the value of HPV tests with or without cytology in determination of recurrent/residual disease.

The aim of our study is to determine the values of traditional cytological test, HPV testing, and surgical margin positivity in determination of recurrent/residual disease among patients who were applied both cytological test and HPV test at the sixth months follow up of the LEEP treatment after the initial diagnosis of CIN 2/3. Prevention of frequent physical examination and unnecessary tests, and reducing patient anxiety might be possible with application of this newly developed test in clinical follow up of these cases.

\section{MATERIAL AND METHOD}

This study is performed via retrospective analysis of 77 patients who initially had CIN2/3 lesions, undergone LEEP, and being followed up for six months in obstetrics and gynecology clinic of the application and research hospital of Mersin University Faculty of Medicine.

All patients were performed LEEP under general anesthesia after being diagnosed to have CIN 2/3 lesions with colposcopy directed biopsy. Surgical procedures were applied by same team of surgeons. For determination of margins of the lesion at the time of surgery, lugol iodine was sometimes used but colposcopy was not used. Six months after these procedures, conventional cytology, HR-HPV (type $16,18,31,33,35,39,45,51,52,56,58,59,68,73$ and 82 ) test with PCR method, colposcopy directed biopsy with endocervical curettage were applied to all patients.

Presence of recurrent/residual disease was determined with assumption of pathologic examination as the gold standard. Surgical margin positivity of the initial LEEP material, conventional cytology results obtained at the sixth month and HR-HPV test performed at the sixth month were compared with pathology results. Socio-demographic properties of the cases and relationship of these data with recurrent/residual disease was evaluated. SPSS 11.5 and MedCalc 11.0.1 was used in statistical analysis.

\section{RESULTS}

Mean (min-max) age of the 77 CIN2/3 cases included in the study is 41.5 (30-65). Demographical properties of the cases were summarized in Table 1. Most of the cases are found to be smokers $(66.2 \%)$, vaginal delivered (74\%), and graduates of primary school (53.2\%). Having first sexual experience at adolescent period is $58.4 \%$. Having a single sexual partner (monogamy) is accepted among women $(87 \%)$ than their male partners $(66.2 \%)$, so polygamy is more frequent among men than women. Among all contraceptive methods, barrier method is found to be the least popular (3.9\%).

Histopathologic evaluation of the LEEP specimen revealed CIN-3 in $77.6 \%$, and CIN-2 in $23.4 \%$ of the 77 cases. Surgical margin positivity is $32.5 \%$ $(n=25)$. Surgical margin positive cases are predominantly CIN-3 cases $(96 \%, n=24)$. All cases were followed for six months without any re-excisional procedure, regardless of surgical margin positivity.

Six months after primary treatment, samples from all patients were obtained for conventional cytology and HR-HPV PCR test. All patients were undergone colposcopy directed biopsy and endocervical curettage in order to determine recurrent/residual disease rate, which is found to be $18 \%(n=14)$. The rest of the patients lacking any histopathologic abnormality in their obtained specimens were accepted to be cured. Recurrent/residual disease is CIN-2 in $14.3 \%(n=2)$, and CIN-3 in $87.7 \%(n=12)$ of the cases. Conventional cytology results were negative in $66.2 \%(\mathrm{n}=51)$, and positive in $33.8 \%$ $(n=26)$ of the 77 cases. Bethesda 2001 classification of cytology positive cases was demonstrated in Table 2 .

Recurrent/residual disease is seen in 2 of the 51 cytology negative cases $(3,9 \%)$, and in 12 of the 26 cytology positive cases $(46 \%)$. HPV test results were positive in $13(17 \%)$, and negative in 64 $(83 \%)$ cases. Recurrent/residual disease rate is $92 \%$ ( $\mathrm{n}=12$ in 13 cases) among HPV positive cases, and $3 \%(\mathrm{n}=2$ in 64 cases) among HPV negative cases. Recurrent/residual CIN2/3 is found in $28 \%(n=7)$ of the surgical margin positive cases $(\mathrm{n}=25)$, and 


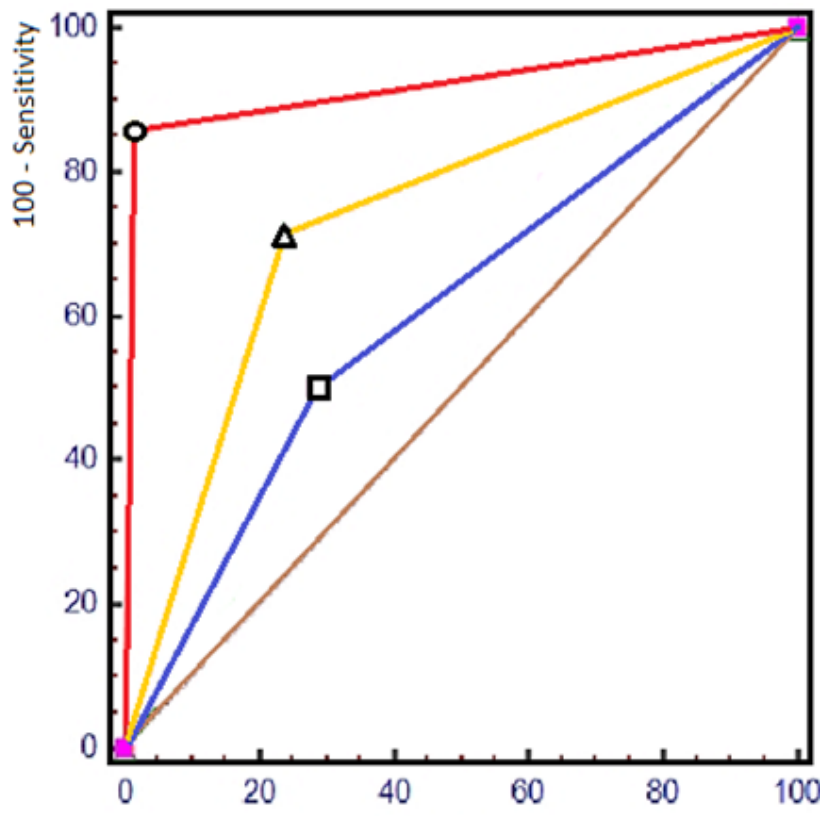

$$
\begin{aligned}
& \text {-O- HPV } \\
& \boldsymbol{\Delta} \text { - Smear Abnormality } \\
& -\mathbf{-} \text { - Surgical margin }
\end{aligned}
$$

100 - Spesificity

Graphic: Predictive power of HPV, cytology and surgical margin.

Table 1: Demographic characteristics.

\begin{tabular}{|l|c|c|}
\hline & (n=77) & \% \\
\hline Smokers & 51 & 66.2 \\
\hline Non-smokers & 26 & 33.8 \\
\hline Ceserean Delivery & 15 & 19.5 \\
\hline Vaginal Delivery & 57 & 74.0 \\
\hline Nullipara & 5 & 6.5 \\
\hline Primay School Graduates & 45 & 58.4 \\
\hline High School Graduates & 27 & 35.1 \\
\hline College or Higher Graduates & 5 & 6.5 \\
\hline Partner is primary school graduate & 41 & 53.2 \\
\hline Partner is High School Graduate & 28 & 36.4 \\
\hline Partner is College or Higher Graduate & 8 & 10.4 \\
\hline First intercourse at 14-20 years & 45 & 58.4 \\
\hline First intercourse at 21-30 years & 31 & 40.3 \\
\hline First intercourse at 31-40 years & 1 & 1.3 \\
\hline Oral contraceptive users & 13 & 16.9 \\
\hline Barrier method users & 3 & 3.9 \\
\hline Intrauterine device users & 26 & 36.4 \\
\hline No contraception & 10 & 42.9 \\
\hline Cases with single sex partner & 37.0 \\
\hline Cases with multiple sex partners & 33.8 \\
\hline Partner has single sex partner & 26 & 66.2 \\
\hline Partner has multiple sex partners & 37.0 \\
\hline
\end{tabular}

Table 2: Bethesda classification of cytological abnormalities.

\begin{tabular}{|l|c|c|}
\hline & $\mathbf{n}(\mathbf{2 6})$ & (\%) \\
\hline ASCUS & 13 & 50.0 \\
\hline LSIL & 1 & 3.8 \\
\hline ASC-H & 4 & 15.4 \\
\hline HSIL & 8 & 36.8 \\
\hline
\end{tabular}

$13.1 \%(n=7)$ of the surgical margin negative cases $(\mathrm{n}=52)$, (Table 3). After evaluation of HPV DNA, cytology,and surgical margin positivity; HPV DNA test was found to be the most useful test for determination recurrent/residual CIN $2 / 3$ cases ( $p$ values were $0.0001,0.048$, and 0.001 respectively) (Table 4, Graphic 1).

\section{DISCUSSION}

Precursor lesions (CIN-2 and CIN-3) of invasive cervical cancer should be treated because of high progression rate and unpredictable behavior (2). Although in pregnancy and adolescent periods these lesions may be closely followed up under some circumstances, there are two main treatment options. Ablative methods are still available and the most frequently used methods of previous treatment modalities. However, the most disadvantageous points are inability to obtain histopathologic specimen, and necessity of visualization of the lesion before treatment. In the second option, the most frequently used excision methods are LEEP and conization. LEEP is most widely accepted to be the standard treatment approach lately. It also prevents excision of unnecessarily wide and healthy tissues besides sampling adequate tissue for histopathology examination.

Success rates of all treatment models are similar. Even in successfully treated cases invasive cancer development is 4-5 times more frequent than normal population (3), unsuccessful treatment frequently end up in progression to invasive cancer. So, there is a necessity to follow up all treated patients. However, there is no clarity on how LEEP treated patients should be followed up. Traditional method offers six months interval cytological follow up, which has high false negativity, low sensitivity. Necessity of long term follow-up, and frequent test repetitions emerge the needs for new follow-up tests. Thus, HR-HPV infection and cervical cancer relationship is near $100 \%$, HPV DNA test could be thought as a candidate for follow-up $(4,5)$. Recently, with the foreseeing that screening for HR-HPV types may reduce the need for long term follow-up, several studies mostly retrospective were committed. In preliminary ones, since HPV and cytology were found to have similar efficacy, it was commented that HPV DNA results would not change long term follow-up policy $(6,7)$. There are studies reporting that the combination of these tests would not have beneficial effect other than increasing workload of colposcopy $(8,9)$.

Beside these, in a large systematic review HPV test and cytology combination was found to have increased sensitivity, specificity, and negative predictive value (10). In our study, HPV DNA test performed after sixth months is found to have higher sensitivity, specificity, positive predictive value, and negative predictive value than either cytology or surgical margin positivity. Our findings contrast previous studies reporting same efficacy for both tests $(6,11)$. Studies supporting our study also 
mentioned importance of HPV positivity in first 3-6 months, and good correlation of HPV negativity with both cytological and histopathologic results (12-14). It may be speculated that re-infection may impair interpretation of recurrent/residual disease status but we think our follow-up interval is quite short for possible lesions after re-infection.

It is worth mentioning that the mean age or the study group is fairly high being over 40 . Multiparity with vaginal delivery, low education level, less frequent use of condoms, and male poligamic sexual lifestyle are also remarkable. All these factors are well known and accepted risk factors.

Surgical margin positivity of the study is $32.5 \%$. It is concordant wih previously reported results which were as high as $40 \%$ (15). Although there are some speculations for margin positivity to increase future recurrent/residual disease, common opinion supports monitorization other than re-excision $(16,17)$. We did not perform repeated LEEP to any patients because of surgical margin positivity, but paid attention to make first control visit in six months' time. In a study of Ayhan A. et al. invasive cervical cancer was reported to be as high as $10.2 \%$ in LEEP re-applied surgical margin positive patient group, we did not find more advanced lesion than CIN-3 in any of the surgical margin positive cases evaluated via colposcopy and colposcopy directed biopsy (18).

It is noteworthy that $96 \%$ of surgical margin positive cases were CIN-3. As far as we know, there is no such study demonstrating the relationship between margin positivity and CIN grade. We found recurrent/residual disease rate to be $28 \%$, which is concordant with previously reported 10-33\% (19). However, it should be kept in mind that as much as $13.1 \%$ of surgical margin negative cases we defined have recurrent disease. In case of cytologic negativity recurrent/residual CIN rate was found to be as low as $3.9 \%$.
In recent years, instead of cocktail based HRHPV DNA, tests prioritizing HPV genotyping became popular $(11,20-22)$. Detection of same HPV type after LEEP, and especially persistence of some HPV types such as 16 and 18 are mentioned to be at most importance $(11,20)$. Type specific HPV infection one year after treatment was reported to be $10 \%$. All previous studies and this study suggest that HPV test would be valuable in follow-up of such patients.

\section{CONCLUSION}

This study demonstrates that HPV test performed six months after initial LEEP therapy predicts recurrent/residual disease superior than conventional cytology. HPV test could be used solely for determination of treatment failures after LEEP. HR-HPV absent, test negative patients are unlikely to have a lesion, but test positive cases should be directed to colposcopic evaluation.

\section{REFERENCES}

1. Garcia-Hernandez E, Gonzalez-Sanchez JL, Andrade-Manzano A et al. Regression of papilloma high-grade lesions (CIN 2 and CIN 3) is stimulated by therapeutic vaccination with MVL E2 recombinant vaccine. Cancer Gene Ther. 2006 June;13(6):592-7.

2. Pinda AV, Crum CP, Natural history of cervical neoplasia :defining progression and its consequences. Clin Obstet Gynecol. 2000 Jun;43(2):352-62.

3. Nuovo J, Melnikow J, Willan AR, Chan BK Treatment Outcomes for squamous intraepithelial lesion. Int $J$ Gynaecol Obstet. 2000 Jan;68(1):2553-68.

4. Wright TC Jr, Massad LS, Dunton CS, Spitzer M, Wilkinson EJ, Solomon D. 2006 Consensus guidelines for the management of woman with cervical intraepithelial neoplasia or adenocarcinoma in situ. J Low Genit Tract Dis 2007 Oct;11(4):223-239.

Tablo 3: Recurrent/Residual CIN2/3 cases according to HPV, cytology, and surgical margin.

\begin{tabular}{|l|c|c|c|}
\hline Parameter at th $^{\text {th }}$ month & $\mathbf{n ( 1 4 )}$ & CIN 2/3 (\%) & p \\
\hline Negative HPV test & 2 & 14.3 & 0.0001 \\
\hline Positive HPV test & 12 & 85.7 & 0.48 \\
\hline Negative Cytology & 4 & 29 & \\
\hline Positive Cytology & 10 & 71 & 0.001 \\
\hline Negative Surgical Margin & 7 & 50 & \\
\hline Positive Surgical Margin & 7 & 50 & \\
\hline
\end{tabular}

Table 4: HPV DNA test, cytology, and surgical margin for predicting recurrent/residual CIN 2/3 cases.

\begin{tabular}{|c|c|c|c|}
\hline & HPV DNA & Cytology & Surgical margin \\
\hline Sensitivity (\%) & $87.5 \quad(57.2-98.4)$ & $40.0 \quad(21.1-61.3)$ & $50.0 \quad(23-77)$ \\
\hline Specificity (\%) & (91.5- 100) & $92.1 \quad(81.5-97.3)$ & $71.3 \quad(58.7-82.1)$ \\
\hline Positive Predictive Value & $92.1 \quad(64-99)$ & $71.2 \quad(40.7-92.1)$ & $28.0 \quad(12.1-49.4)$ \\
\hline Negative Predictive Value & $96.7 \quad(89.1-99.6)$ & $76.0 \quad(63.7-86.1)$ & $86.5 \quad(74.1-94.4)$ \\
\hline Positive LHR & $54.0 \quad(43.5-67)$ & $5.2 \quad(3.2-8.5)$ & $1.75 \quad(1-3)$ \\
\hline Negative LHR & $0.15 \quad(0.01-1.5)$ & $0.65 \quad(0.2-1.8)$ & $0.70 \quad(0.4-1.3)$ \\
\hline Area Under Curve & $0.921 \quad(0.83-0.97)$ & $0.66 \quad(0.54-0.76)$ & $0.60 \quad(0.48-0.71)$ \\
\hline
\end{tabular}


5. Walboomers JM, Jacobs MV, Manos MM, et al. Human papillomavirus is a necessary cause of invasive cervical cancer world wide J Pathol. 1999 Sep;189(1);1219.

6. Costa S, De Simone P, Venturoli $S$ et al. Factors predicting human papillomavirus, clearance in cervical intraepithelial neoplasia lesion treated by conization $G y$ necol Oncol. 2003 Aug;90(2):358-365.

7. Strander B, Ryd W, Wallin KL, Varelby B, Zheng $B$ et al. Does HPV status 6-12 months after treatment of high grade dysplasia in the uterine cervix predict long term recurrence Eur J Cancer 2007 Aug;43(12):18491855.

8. Sarian LO, Derchain SF, Andrade LA,Tambascia J, Morris SS et al. HPV DNA test and PAP smear in detection of residual/recurrent disease following loop electrosurgical excision procedure of high-grade cervical intraepithelial neoplasia. Gynecol Oncol. 2004 Jul;94(1):181-186.

9. Aschkenazi-Steinberg SO, Spitzer BJ, Spitzer M, Lesser $M$, The clinical usefulness of human papillomavirus testing in the follow-up of women after treatment for cervical intraepithelial neoplasia. J Low Genit Tract Dis. 2004 Oct; $8(4): 304-307$.

10. Zielinski GD, Bais AG, Helmerhorst TJ, Verheijen RH et al. HPV testing and monitoring of women after treatment of $C I N-3$ A review of the literature and meta-analysis. Obstet Gynecol Surv. 2004 Jul;59(7):543-553.

11. Kang WD, Oh MJ, Kim SM, Nam JH et al. Significance of human papilloma virus genotyping with high-grade cervical intraepithelial neoplasia treated by loop electrosurgical excision procedure Am J Obstet Gynecol. $2010 \mathrm{Jul} ; 203(1): 72: 1-6$.

12. Lequevaque P, Motton S, Decharme A, Soule-Tholy $M$, Escourrou G, Hoff J. Predictors of recurrence in high grade cervical lesions and plan of management Euro $J$ Surg Oncol. 2010 Nov;36(11):1073-1079.

13. Fuste P, Bellosillo B, Santamaria X, Mancebo G, Marinoso L et al. HPV determination in the control after leep due to CIN II-III: prospective study and predictive model. Int J Gynecol Pathol. 2009 Mar;28(2):120-126.
14. Park JY, Bae J, Lim MC, Lim SY, Lee DO, Kang S, Park SY, et al. Role of high risk human papillomavirus test in the follow-up of patients who underwent conization of the cervix for cervical intraepithelial neoplasia $J$ Gynecol Oncol. 2009 Jun;20(2):86-90.

15. Murdoch JB, Morgan PR, Lopes A, Monaghan JM, Hystological incomplet excision of CIN after large loop excision of the transformation zone (LLETZ). Merits careful follow up, not treatment. Br J Obstet Gynecol. 1992 Dec;99(12):990-993.

16. Kalagirou D, Antoniou $G$, Karakitsos P, Botsis D, et al. Predictive factors used to justify hysterectomy after loop conization : increasing age and severity of disease. Eur J Gynecol Oncol. 1997;18(2):113-116.

17. Moore BC, Higgins RV, Laurent SL, Marroum M, et al. Predictive factors from cold knife conization for residual cervical intraepithelial neoplasia in subsequent hysterectomy. Am J Obstet Gynecol. 1995 Aug;173(2):361366.

18. Ayhan A, Boynukalin FK, Güven S, Dogan NU, Esinler I, Usubutun A. Repeat LEEP conization in patients with cervical intraepithelial neoplasia grade 3 and post ectocervical margins. Int J Gynaecol Obstet. 2009 Apr;105(1):14-17.

19. Gardeil F, Barry-Walsch C, Prendiville W, Clinch $J$. et al. Persistent intraepithelial neoplasia after excision for cervical intraepithelial neoplasia grade III. Obstet Gynecol. 1997 Mar;89(3):419-422.

20. Wu D, Zheng Y, Chen W, Guo C, Yu J, Chen G, et al. Prediction of residual/recurrent disease by HPV genotype after loop excision procedure for high grade cervical intraepithelial neoplasia with negative margins. Aust $N Z$ J Obstet Gynaecol. 2011 Apr;51(2):114-118.

21. Bae JH, Kim CJ, Park TC, Namkoong SE, Park $J S$, Persistance of human papillomavirus as a predictor for treatment failure after loop electrosurgical excision procedure. Int J Gynecol Cancer. 2007 NovDec;17(6):1271-1277.

22. Brismar S, Johansson B, Borjesson M, Arbyn $M$, Anderson S. Follow up after treatment of cervical intraepithelial neoplasia by human papillomavirus genotyping. Am J Obstet Gynecol. 2009 Jul;201(1);17:1-8. 